\title{
PENGARUH PENGALAMAN KERJA, PRESTASI KERJA SERTA PENDIDIKAN DAN PELATIHAN TERHADAP PENGEMBANGAN KARIR KARYAWAN
}

\author{
Ida Ayu Diah Sri Gayatri ${ }^{1}$ \\ Anak Agung Ayu Sriathi ${ }^{2}$ \\ Fakultas Ekonomi dan Bisnis Universitas Udayana (Unud), Bali, Indonesia \\ email: idaayudiah24@yahoo.com
}

\begin{abstract}
ABSTRAK
Penelitian ini memiliki tujuan mengetahui pengaruh pengalaman kerja, prestasi kerja serta diklat terhadap pengembangan karir karyawan. Lokasi penelitian ini adalah Uppala Villa \& Spa Umalas. Populasi dalam penelitian terdiri dari semua karyawan di Uppala Villa \& Spa Umalas. Responden yang digunakan dalam penelitian ini yaitu jumlah populasi sebanyak 49 responden yang merupakan seluruh karyawan di Uppala Villa \& Spa Umalas. Status dari seluruh karyawan yaitu sebagai karyawan tetap. Teknik analisis yang digunakan adalah analisis regresi linier berganda. Berdasarkan penelitian yang telah dilakukan diperoleh bahwa pengalaman kerja memiliki pengaruh positif dan signifikan terhadap pengembangan karir yang berarti apabila pengalaman kerja semakin lama maka pengembangan karir yang dimiliki karyawan di Uppala Villa \& SPA Umalas akan meningkat. Prestasi kerja memiliki pengaruh positif dan signifikan terhadap pengembangan karir. Hasil penelitian juga menunjukan bahwa pendidikan dan pelatihan memiliki pengaruh positif dan signifikan terhadap pengembangan karir karyawan.

Kata kunci: pengalaman kerja, prestasi kerja, pendidikan, pengembangan karir
\end{abstract}

\begin{abstract}
This study aims to determine the effect of work experience, work performance and education and training on employee career development. The location of this research is Uppala Villa \& Spa Umalas. The population in this study were all employees at Uppala Villa \& Spa Umalas. Respondents used in this study are the total population of 49 respondents who are all employees at Uppala Villa \& Spa Umalas. Status of all employees, namely as permanent employees. The analysis technique used is multiple linear regression analysis. The results of this study indicate that work experience has a positive and significant effect on career development which means that if work experience is getting longer the career development owned by employees at Uppala Villa \& SPA Umalas will increase. Job performance has a positive and significant effect on career development. The results also showed that education and training had a positive and significant effect on employee career development.
\end{abstract}

Keywords: work experience, work performance, education, career development 


\section{PENDAHULUAN}

Persaingan global dewasa ini, setiap perusahaan dituntut untuk terus meningkatkan kualitas sumber daya manusianya. Sumber daya manusia yang dapat dikatakan berkualitas adalah sumber daya manusia yang memiliki keterampilan, kemampuan, pengetahuan dan sikap yang baik dalam bekerja. Peningkatan kualitas sumber daya manusia dapat dilakukan dengan cara memaksimalkan efektivitas dan efisiensi perusahaan yang bisa ditempuh melalui pengembangan karir karyawan. Setiap sumber daya manusia yang bekerja dalam suatu organisasi pasti menginginkan pengembangan pada karirnya.

Karir yang berkembang sering kali dikaitkan dengan masa depan karyawan, walaupun belum menjamin suatu kesuksesan. Kesuksesan karir membawa arti yang berbeda untuk masing-masing individu karyawan (Ali, 2013). Karir merupakan pola dari pekerjaan dan sangat berhubungan dengan pengalaman (posisi, wewenang, keputusan dan interpretasi subyektif atas pekerjaan) dan aktivitas selama masa kerja individu (Rivai, 2011). Penelitian yang dilakukan Zhan et al, (2008) menyatakan bahwa kemajuan karir dalam organisasi dilihat dari pencapaian karir saat ini. Caroline et al. (2014) menyatakan bahwa di dalam suatu organisasi seorang pimpinan yang mengharapkan pencapaian kinerja agar maksimal akan memperhatikan faktor-faktor yang mempengaruhi kinerja pegawainya, salah satunya adalah pengembangan karir.

Crowley et al. (2012) mengatakan bahwa pengaruh pengembangan karir berimbas pada arah dalam diri. Charity (2015) menyatakan bahwa pengembangan karir adalah proses dimana karyawan secara strategis mengeksplorasi, merencanakan, dan menciptakan masa depan mereka di tempat kerja dengan merancang rencana pembelajaran pribadi untuk mencapai potensi mereka dan memenuhi persyaratan misi organisasi. Khan et al. (2015) berpendapat bahwa pengembangan karir karyawan memainkan peran penting dalam memperkaya komponen modal manusia suatu perusahaan. Pengembangan karir tidak hanya bermanfaat bagi karyawan, tetapi juga bagi organisasi. Praktik pengembangan karir memungkinkan organisasi untuk mengembangkan dan menempatkan karyawan pada posisi yang sesuai dengan minat, kebutuhan, dan tujuan karir individu mereka (Kakul \& Gachunga, 2016). Dukungan pengembangan karir yang fleksibel dalam desain pekerjaan dan fleksibel dalam perencanaan pengembangan karir muncul sebagai strategi pengembangan karir positif yang akan mempengaruhi persepsi karyawan terhadap kehidupan kualitas kerja.

Sutrisno \& Edy (2009) menyatakan bahwa ada lima faktor yang akan mempengaruhi lancar atau tidaknya karir seorang karyawan. Untuk itulah kelima faktor tersebut harus dikelola oleh karyawan dengan baik, apabila karyawan yang bersangkutan ingin meraih karir ke jenjang yang lebih tinggi, faktor tersebut yaitu antara lain sikap atasan, rekan sekerja dan bawahan, pengalaman, pendidikan, prestasi dan faktor nasib. A. Sitohang (2007) juga berpendapat bahwa salah satu faktor yang mempengaruhi pengembangan karir seorang karyawan yaitu pengalaman kerja. 
Oertle et al. (2007) mengatakan bahwa pengalaman kerja dijadikan sebagai salah satu komponen penting untuk mengembangkan karir karyawan di perusahaan. Pengalaman merupakan suatu proses pembelajaran dan pertambahan pada perkembangan potensi bertingkah laku baik dari pendidikan formal maupun nonformal atau dapat diartikan sebagai suatu proses yang membawa seseorang kepada suatu pola tingkah laku yang lebih baik (Zainullah et al., 2013). Butcher (2008) berpendapat bahwa pengalaman merupakan aset yang dapat digunakan untuk mencapai suatu karir yang lebih baik. Pengalaman kerja bukanlah satu satunya yang dinilai dalam menentukan pengembangan karir karyawan, melainkan masih ada prestasi kerja beserta pendidikan dan pelatihan.

Prestasi kerja merupakan perwujudan seseorang dalam melaksanakan pekerjaannya (Sunyoto \& Danang, 2012). Saeed et al. (2014) menyatakan bahwa prestasi kerja adalah keterampilan yang dimiliki oleh seorang karyawan untuk melakukan berbagai pekerjaan yang berkaitan dengan kebutuhan pekerjaan. Menurut Borman dan motowidlo dalam Asim et al. (2012) menyatakan bahwa prestasi kerja adalah sebuah hasil kerja yang dilakukan karyawan dari waktu ke waktu. Prestasi kerja adalah suatu hasil kerja yang dicapai seseorang dalam melaksanakan tugas-tugas yang dibebankan kepadanya yang didasarkan atas kecakapan, pengalaman, dan kesungguhan, serta waktu (Hasibuan \& Malayu, 2013). Menurut Soeprihanto \& John (2009) prestasi kerja adalah sebuah hasil kerja seseorang selama batas periode tertentu, ketika suatu prestasi kerja tidak dapat memenuhi syarat yang sudah di tetapkan, maka manajer harus mengambil tindakan dalam menindaki hal tersebut, demikian juga apabila prestasi kerja pegawai tersebut bagus maka perilakunya perlu dipertahankan.

Pendidikan dan pelatihan (diklat) merupakan suatu upaya dalam mengembangkan sumber daya manusia (Hidayat \& Nurasyiah, 2016). Hasibuan \& Malayu (2001) berpendapat bahwa pendidikan dan pelatihan (diklat) sesungguhnya tidak sama, walaupun banyak persamaannya yaitu keduanya berhubungan erat dengan pemberian bantuan kepada karyawan agar karyawan tersebut dapat berkembang ketingkat kecerdasan, pengetahuan dan kemampuan yang lebih tinggi. Kasmuni et al. (2016) menjelaskan pendidikan dan pelatihan (diklat) secara terpisah sebagai berikut. Pendidikan berkaitan dengan upaya menambah, meningkatkan pengetahuan dan pemahaman umum mengenai satu bidang, sehingga pengetahuan dan pemahaman dalam suatu bidang tersebut meningkat. Sedangkan pelatihan merupakan proses sistematik pengubahan, perilaku, dan tindakan karyawan dalam suatu arah untuk mencapai tujuan tujuan organisasional. Falola et al. (2014), menyatakan pendidikan dan pelatihan (diklat) merupakan suatu teknik yang digunakan untuk mengajarkan keterampilan, pengetahuan, dan kompetensi tertentu dengan tujuan meningkatkan kemampuan karyawan dalam menyelesaikan tugas yang diberikan.

Penelitian ini dilakukan di Uppala Villa \& Spa Umalas yang merupakan perusahaan yang bergerak dalam bidang jasa (pelayanan) yaitu villa dan spa yang berada di Kerobokan, Kuta Utara, Badung. Walaupun perusahaan ini merupakan satu dari banyak perusahaan besar yang bergerak dalam bidang villa dan spa, namun ada beberapa aspek yang belum terasa optimal. Mengingat kebutuhan wisatawan yang semakin tinggi akan jasa penginapan, maka dari itu perusahaan selalu 
berusaha dalam menciptakan kinerja karyawan yang baik untuk dapat mempertahankan kualitas perusahaan agar tetap mampu mempertahankan visi dan misi perusahaan. Saat ini karyawan Uppala Villa \& Spa Umalas pada tahun 2019 berjumlah sebanyak 49 orang dapat di lihat pada Tabel 1.

\section{Tabel 1.}

Jumlah Karyawan Uppala Villa \& Spa Umalas pada Tahun 2019

\begin{tabular}{ccc}
\hline No & Posisi & Jumlah (Orang) \\
\hline 1 & Front Office & 7 \\
2 & HRD & 7 \\
3 & Accounting & 4 \\
4 & Sales \& Marketing & 2 \\
5 & Housekeeping & 13 \\
6 & Engineering & 5 \\
7 & Food and Beverage Product & 6 \\
8 & Food and Beverage Service & 3 \\
9 & Therapist & 2 \\
& Jumlah & $\mathbf{4 9}$ \\
\hline
\end{tabular}

Sumber: Uppala Villa \& Spa Umalas, 2019

Tabel 1. menunjukkan bahwa jumlah karyawan Uppala Villa \& Spa Umalas pada tahun 2019 sebanyak 49 orang. Berdasarkan dari jumlah karyawan tersebut, tentunya tidak sedikit permasalahan yang dijumpai. Berdasarkan hasil pra-riset dari hasil wawancara yang dilakukan terhadap 10 orang karyawan Uppala Villa \& Spa Umalas permasalahan yang terjadi pada karyawan tersebut yaitu adanya keinginan terhadap karir mereka agar selalu lancar, tetapi hal tersebut sering tidak menjadi kenyataan. Kurangnya peluang promosi yang dimiliki karyawan menyebabkan akses untuk mengetahui lowongan jabatan yang ada di perusahaan sangat terbatas, hanya orang-orang tertentu saja yang mengetahui informasi mengenai lowongan jabatan yang ada di perusahaan tersebut. Kesempatan untuk tumbuh dan meningkatkan karir bagi seorang karyawan dapat dilihat dari pengalaman kerja yang cukup, prestasi kerja yang diraih karyawan serta seberapa jauh telah mengikuti berbagai pendidikan dan pelatihan yang diselenggarakan oleh pihak perusahaan.

Permasalahan pertama yang ditemukan yaitu masih banyak karyawan yang pengalamannya belum memadai. Kondisi ini dapat dilihat dari adanya temuan pada beberapa orang karyawan yang belum terampil dalam mengerjakan pekerjaannya, padalah dengan memiliki pengalaman kerja akan dapat membantu karyawan dalam kelancaran saat bekerja dan dapat mengerjakan tugas tanpa perlu menunggu perintah. Minimnya pengalaman kerja yang dimiliki karyawan, tidak lepas pula dari masa kerja di perusahaan tempat mereka bekerja. Tabel 2. menunjukkan masa kerja karyawan Uppala Villa \& SPA Umalas.

Tabel 2. menunjukkan bahwa pada masa kerja karyawan yang $\leq 5$ tahun yaitu sebanyak 34 orang. Hal ini menunjukkan bahwa pengalaman kerja yang dimiliki karyawan dengan masa kerja tersebut masih kurang atau tidak sebanyak karyawankaryawan yang memiliki masa kerja lebih lama. Ardana et al. (2012) menyatakan adanya kecenderungan bahwa semakin lama bekerja, maka akan semakin banyak pengalaman yang dimiliki oleh tenaga kerja yang bersangkutan. Artinya semakin banyak pengalaman kerja yang dimiliki seorang karyawan, maka akan semakin 
memungkinkan untuk dapat memperoleh pengembangan karir di perusahaan. Begitu pula sebaliknya, jika seorang karyawan tidak memiliki pengalaman kerja yang cukup maka akan sulit baginya untuk bisa memperoleh peningkatan jabatan di perusahaan.

Tabel 2.

Masa Kerja Karyawan Uppala Villa \& Spa Umalas Tahun 2019

\begin{tabular}{ccc}
\hline No & $\begin{array}{c}\text { Masa Kerja } \\
\text { (Tahun) }\end{array}$ & $\begin{array}{c}\text { Jumlah } \\
\text { Karyawan (Orang) }\end{array}$ \\
\hline 1 & $\leq 5$ & 34 \\
2 & $6-10$ & 15 \\
3 & $11-15$ & - \\
4 & $16-20$ & - \\
5 & $\geq 20$ & - \\
& Jumlah & $\mathbf{4 9}$ \\
\hline
\end{tabular}

Sumber: Uppala Villa \& Spa Umalas, 2019

Permasalahan kedua dalam pengembangan karir karyawan Uppala Villa \& SPA Umalas yaitu prestasi kerja karyawan yang rendah karena karyawan belum cekatan dalam mengerjakan tugas yang di berikan oleh atasannya. Ini disebabkan karena masih ada beberapa karyawan yang tidak memenuhi syarat dalam menduduki suatu jabatan. Kurangnya kompetensi yang dimiliki karyawan menjadi satu dari banyak penyebab prestasi kerja karyawan rendah. Muamarizal et al. (2015) mengatakan bahwa semakin tinggi prestasi kerja yang dimiliki seorang karyawan maka semakin besar peluangnya untuk mendapatkan kemajuan karir diperusahaan. Sebaliknya, peningkatan karir akan sulit diperoleh apabila prestasi karyawan yang bersangkutan dinilai kurang baik oleh perusahaan.

Kesempatan untuk tumbuh dan meningkatkan karir bagi seorang karyawan dapat melalui salah satunya dengan mengikuti berbagai program pendidikan dan pelatihan yang diselenggarakan oleh pihak perusahaan. Untuk itu Uppala Villa \& Spa Umalas senantiasa melakukan pengembangan karir karyawannya dengan mengadakan beberapa jenis program pendidikan dan pelatihan yang biasa disebut dengan diklat, terutama untuk masa kerja karyawan yang masih tergolong baru. Jenis pendidikan dan pelatihan yang pernah diadakan di Uppala Villa \& Spa Umalas dapat dilihat pada Tabel 3.

Tabel 3.

Jenis Pendidikan dan Pelatihan yang dilaksanakan Uppala Villa \& Spa Umalas pada Tahun 2017-2019

\begin{tabular}{clc}
\hline No & Jenis Pelatihan & Tanggal Pelaksanaan \\
\hline 1 & How to use EDC mesin & 24 Agustus 2017 \\
2 & Train the trainer & 8 Januari 2018 \\
3 & Set up trolley & 24 Februari 2018 \\
4 & How to make new menu & 12 juni 2018 \\
5 & Pelatihan standar teraphist & 23 Juli 2018 \\
6 & Greeting and telepon conversation & 21 September 2018 \\
7 & Standard set up breakfast buffet & 22 Oktober 2018 \\
8 & Pelatihan Gada Pratama & 20 Maret 2019 \\
& & \\
\hline
\end{tabular}

Sumber: Uppala Villa \& Spa Umalas, 2019 
Tabel 3. menunjukkan bahwa terdapat 8 jenis pendidikan dan pelatihan yang diselenggarakan oleh pihak manajemen Uppala Villa \& Spa Umalas pada tahun 2017-2019. Program pendidikan dan pelatihan (diklat) ini diharapkan dapat memberikan manfaat dan menambah pengetahuan bagi seluruh karyawan itu sendiri serta dapat meningkatkan karir mereka di perusahaan. Permasalahan terakhir yang ditemukan yaitu terkait dengan pelaksanaan program pendidikan dan pelatihan (diklat) yang kurang disosialisasikan, sehingga menyebabkan adanya ketidakjelasan program dan aturan, terutama mengenai kriteria yang membuat seorang karyawan bisa dapat terpilih untuk menjadi peserta pendidikan dan pelatihan. Serta jadwal pendidikan dan pelatihan (diklat) yang terbentur dengan waktu kerja karyawan, sehingga dapat mengganggu operasional rutin karyawan.

Pengembangan karir adalah proses dimana peningkatan keterampilan kerja seseorang mendorong adanya peningkatan penilaian kinerja yang bertujuan mencapai karir yang diinginkan. Pengalaman kerja yang cukup dimiliki karyawan akan mampu memberikan kepuasan kerja pada setiap karyawan yang akan berpengaruh pada peningkatan karirnya. Pengalaman kerja berkaitan dengan pengembangan karir karena dengan memiliki banyak pengalaman kerja akan membantu seseorang dalam menyelesaikan tugas-tugasnya tanpa perlu menunggu perintah, selain itu pengalaman kerja juga mempermudah karyawan mengerjakan tugas-tugas yang diberikan karena sudah memiliki kemampuan yang didapat dari pengalaman pengalaman bekerja sebelumnya.

Pengalaman kerja adalah suatu dasar atau acuan seorang karyawan dapat menempatkan diri secara tepat kondisi, berani mengambil risiko, mampu menghadapi tantangan dengan penuh tanggung jawab serta mampu berkomunikasi dengan baik terhadap berbagai pihak untuk tetap menjaga produktivitas, kinerja dan menghasilkan individu yang kompeten dalam bidangnya (Sutrisno \& Edy, 2009) Yunita et al. (2016). menyatakan pengalaman kerja merupakan lama waktu atau masa kerja yang telah ditempuh oleh seorang karyawan untuk dapat memahami seluruh tugas-tugas dalam pekerjaan dan telah melaksanakan dengan baik. Menurut Nitisemito dalam Rofi (2012) pengalaman kerja adalah sesuatu atau kemampuan yang dimiliki oleh para karyawan dalam menjalankan tugas-tugas yang dibebankan kepadanya.

Prestasi kerja adalah suatu hasil kerja yang dicapai seseorang dalam melaksanakan tugas-tugas yang dibebankan kepadanya yang didasarkan atas kecakapan, pengalaman, dan kesungguhan, serta waktu (Hasibuan \& Malayu, 2013), Menurut Borman dan motowidlo dalam Asim et al. (2012) prestasi kerja adalah sebuah hasil kerja yang dilakukan karyawan dari waktu ke waktu. Sutrisno \& Edy (2009) menyatakan prestasi kerja adalah hasil upaya seseorang yang ditentukan oleh kemampuan karakteristik pribadinya serta terhadap peran pekerjaanya. Berdasarkan beberapa pendapat mengenai prestasi kerja di atas, maka dapat dinyatakan bahwa prestasi kerja adalah hasil kerja yang dicapai seorang pegawai melaksanakan tugas-tugas yang telah dibebankan kepadanya selama periode tertentu. Apabila prestasi kerja pegawai tersebut bagus maka perilakunya perlu dipertahankan. 
Hidayat \& Nurasyiah (2016) menyatakan bahwa pendidikan dan pelatihan (diklat) merupakan suatu upaya dalam mengembangkan sumber daya manusia. Kasmuni et al. (2016) menjelaskan pendidikan dan pelatihan secara terpisah sebagai berikut. Pendidikan berkaitan dengan upaya menambah, meningkatkan pengetahuan dan pemahaman umum mengenai satu bidang, sehingga pengetahuan dan pemahaman dalam suatu bidang tersebut meningkat. Sedangkan pelatihan merupakan proses sistematik pengubahan, perilaku, dan tindakan karyawan dalam suatu arah untuk mencapai tujuan tujuan organisasional. Pelatihan (training) sebagai suatu kegiatan yang bermaksud untuk memperbaiki dan mengembangkan sikap, tingkah laku, keterampilan, dan pengetahuan dari karyawan didalam suatu perusahaan.

Falola et al. (2014) menyatakan diklat merupakan suatu teknik yang digunakan untuk mengajarkan keterampilan, pengetahuan, dan kompetensi tertentu dengan tujuan meningkatkan kemampuan karyawan dalam menyelesaikan tugas yang diberikan. Diklat merupakan strategi yang sangat diperlukan untuk menunjang kinerja baik itu individu maupun kelompok dalam suatu organisasi.

Berdasarkan definisi mengenai pendidikan dan pelatihan di atas dapat dinyatakan bahwa pendidikan dan pelatihan mempunyai tujuan yang hampir sama yaitu meningkatkan kualifikasi sumber daya manusia, namun demikian pendidikan dan pelatihan memiliki ruang lingkup yang berbeda. Pendidikan menekankan pada pengembangan individu secara menyeluruh seperti kemampuan kognitif, afektif, dan psikomotorik. Melalui pendidikan diharapkan agar individu dapat beradaptasi dengan baik jika terjadi perubahan lingkungan. Sedangkan pelatihan mengarahkan karyawan kearah penguasaan keterampilan tertentu dan kemampuan menyelesaikan tanggung jawab yang diberikan, sehingga materi yang diberikan pada saat pelatihan bersifat sangat spesifik dan focus penekanan lebih pada psikomotorik dari pada kognitif dan efektif.

Penelitian sejenis yang dilakukan oleh Kristola (2014) menyatakan bahwa pengalaman kerja memiliki pengaruh positif dan signifikan terhadap pengembangan karir karyawan. Hasil penelitian Dewi \& Kartika (2015) juga menyatakan adanya pengaruh positif dan signifikan antara pengalaman kerja terhadap pengembangan karir. Kemudian penelitian oleh Suadnyana (2018) (Suadnyana, 2018) yang dilakukan mendapatkan hasil adanya pengaruh positif dan signifikan antara pengalaman kerja terhadap pengembangan karir karyawan. Penelitian Saraswati \& Andani (2017) yang mendapatkan hasil positif dan signifikan pada pengalaman kerja terhadap pengembangan karir. Dan hasil yang sama juga ditemukan pada penelitian yang dilakukan oleh Arisandy (2015) mendapatkan hasil bahwa pengalaman kerja berpengaruh positif dan signifikan terhadap pengembangan karir. Berdasarkan beberapa hasil penelitian diatas, maka hipotesis yang dapat diajukan dalam penelitian ini adalah sebagai berikut.

$\mathrm{H}_{1}$ : Pengalaman kerja memiliki pengaruh positif dan signifikan terhadap pengembangan karir.

Prestasi kerja adalah kesuksesan yang dicapai seorang karyawan dalam melaksanakan tugas-tugas yang telah dibebankan kepadanya selama periode tertentu. Menurut Soeprihanto \& John (2009) prestasi kerja bermanfaat bagi peneliti dan pengembangan karir pada bidang personalia secara keseluruhan, dan digunakan 
sebagai dasar dalam perencanaan SDM untuk menyempurnakan pada kondisi kerja, peningkatan mutu serta hasil kerja. Berdasarkan hasil peneilitian sebelumnya yang dilakukan oleh Rawashdeh (2013) mengungkapkan adanya pengaruh positif dan signifikan antara penilaian prestasi kerja terhadap sistem pengembangan karir. Hasil yang sama juga dikemukakan oleh Wati \& Mira (2015) yang menemukan hasil yaitu prestasi kerja memiliki pengaruh positif dan signifikan terhadap pengembangan karir karyawan. Penelitian terdahulu Muamarizal et al. (2015) yang dilakukan juga menemukan hasil bahwa penilaian prestasi kerja memiliki pengaruh positif dan signifikan terhadap pengembangan karir pegawai. Penelitian sebelumnya oleh Susanto (2013) juga menyatakan bahwa prestasi kerja memiliki pengaruh positif dan signifikan terhadap pengembangan karir karyawa. Penelitian oleh Sumadewi (2017) menyatakan bahwa adanya pengaruh positif dan signifikan antara prestasi kerja terhadap pengembangan karir. Berdasarkan beberapa hasil penelitian diatas, maka hipotesis yang dapat diajukan dalam penelitian ini adalah sebagai berikut.

$\mathrm{H}_{2}$ : Prestasi kerja memiliki pengaruh positif dan signifikan terhadap pengembangan karir.

Penelitian sebelumnya yang dilakukan oleh Saranani (2015) mengemukakan adanya pengaruh positif dan signifikan antara pendidikan dan pelatihan terhadap pengembangan karir. Kemudian penelitian dari Candra (2016) juga mengemukakan adanya pengaruh positif dan signifikan antara pendidikan dan pelatihan terhadap pengembangan karir. Penelitian lain juga dilakukan oleh Andriyani (2017) hasil dari penelitian ini menyatakan pendidikan dan pelatihan mempunyai pengaruh secara signifikan dan positif terhadap variabel pengembangan karir. Penelitian oleh Nugraha (2014) juga mengatakan pelatihan memiliki pengaruh signifikan dan positif terhadap pengembangan karir karyawan. Hasil yang sama juga dikemukakan oleh Adnyani (2019) yang menyatakan bahwa pelatihan berpengaruh positif dan signifikan terhadap pengembangan karir. Berdasarkan beberapa hasil penelitian di atas, maka hipotesis yang dapat diajukan dalam penelitian ini adalah sebagai berikut.

$\mathrm{H}_{3}$ : Pendidikan dan pelatihan memiliki pengaruh positif dan signifikan terhadap pengembangan karir.

\section{METODE PENELITIAN}

Desain penelitian atau rancangan digunakan untuk menunjang dan memberikan hasil penelitian yang sistematik. Penelitian ini merupakan penelitian kuantitatif yang bertujuan untuk menguji hipotesis yang telah ditetapkan. Jenis penelitian ini merupakan penelitian asosiatif yang bersifat kasual (sebab akibat) yang bertujuan untuk mengetahui hubungan atau pengaruh dari satu variabel atau lebih Sugiyono (2012). Dalam penelitian ini bertujuan untuk mengetahui pengaruh variabel bebas yaitu pengalaman kerja, prestasi kerja dan pendidikan dan pelatihan terhadap variabel terikat yaitu pengembangan karir.

Lokasi penelitian ini dilakukan di Uppala Villa \& Spa Umalas yang beralamat di Jalan Bumbak Dauh, Kerobokan, Kuta Utara, Badung. Alasan memilih lokasi ini karena di lokasi ini belum adanya penelitian tentang pengaruh pengalaman kerja, prestasi kerja, pendidikan dan pelatihan serta pengembangan karir. Objek dari 
penelitian ini adalah pengalaman kerja, prestasi kerja, pendidikan dan pelatihan dan pengembangan karir.

Populasi dalam penelitian ini adalah semua karyawan di Uppala Villa \& Spa Umalas. Responden yang digunakan dalam penelitian ini yaitu jumlah populasi sebanyak 49 responden yang merupakan seluruh karyawan di Uppala Villa \& Spa Umalas. Status dari seluruh karyawan yaitu sebagai karyawan tetap. Metode yang digunakan adalah sampel jenuh (saturated sampling). Distribusi sampel karyawan per jabatan ditunjukan pada Tabel 4.

Tabel 4.

Jumlah per Jabatan Karyawan Uppala Villa \& Spa Umalas

\begin{tabular}{ccc}
\hline No & Posisi & Jumlah (Orang) \\
\hline 1 & Front Office & 7 \\
2 & HRD & 7 \\
3 & Accounting & 4 \\
4 & Sales \& Marketing & 2 \\
5 & Housekeeping & 13 \\
6 & Engineering & 5 \\
7 & Food and Beverage Product & 6 \\
8 & Food and Beverage Service & 3 \\
9 & SPA & 2 \\
\hline
\end{tabular}

Sumber: Uppala Villas \& Spa Umalas, 2019

Teknik analisis regresi linear berganda digunakan untuk menguji pengaruh pengalaman kerja, prestasi kerja, pendidikan dan penelitian terhadap pengembangan karir. Dimana variabel babasnya adalah pengalaman kerja, prestasi kerja, pendidikan dan pelatihan sedangkan vaiabel terikatnya adalah pengembangan karir. Persamaan regresi linear berganda dirumuskan secara matematis sebagai berikut:

$$
\begin{aligned}
\hat{\mathrm{Y}}=\alpha+\mathrm{b}_{1} \mathrm{X}_{1} & +\mathrm{b}_{2} \mathrm{X}_{2}+\mathrm{b}_{3} \mathrm{X}_{3} \text { e........................... } \\
\text { Keterangan: } & \\
\hat{\mathrm{Y}} & =\text { Pengembangan Karir } \\
\alpha & =\text { Koefisien konstanta } \\
\mathrm{X} 1 & =\text { Pengalaman Kerja } \\
\mathrm{X} 2 & =\text { Prestasi Kerja } \\
\mathrm{X} 3 & =\text { Pendidikan dan Pelatihan } \\
\mathrm{b} 1 & =\text { Koefisien regresi dari Pengalaman Kerja }\left(\mathrm{X}_{1}\right) \\
\mathrm{b} 2 & =\text { Koefisien regresi dari Prestasi Kerja }\left(\mathrm{X}_{2}\right) \\
\mathrm{b} 3 & =\text { Koefisien regresi dari Pendidikan dan Pelatihan }\left(\mathrm{X}_{3}\right) \\
\mathrm{e} & =\text { Error }
\end{aligned}
$$

\section{HASIL DAN PEMBAHASAN}

Penelitian ini menggunakan data primer yang didapat dari kuisioner yang dijawab oleh responden Uppala Villa \& SPA Umalas. Jumlah responden yang 
digunakan dalam penelitian ini sebanyak 49 orang. Uraian tentang karakteristik responden menyangkut beberapa aspek yaitu jenis kelamin, usia, dan pendidikan terakhir.

Sebagian besar responden adalah berjenis kelamin laki-laki yaitu sebanyak 35 orang dengan persentase 71,43 persen, sedangkan sisanya perempuan sebanyak 14 orang dengan persentase 28,57 persen. Artinya sebagian besar karyawan Uppala Villa \& SPA Umalas mempekerjakan tenaga laki-laki. Hal ini menunjukan sebagian besar karyawan yang diperlukan untuk bidangnya adalah tenaga kerja laki-laki, karena laki-laki lebih mampu berperan dalam menjalankan tugas perusahaan yang berkaitan dengan fisik. Sebagian besar responden berusia di antara 20-30 tahun dengan persentase sebesar 42,86 persen, sedangkan untuk kelompok usia terendah yaitu pada usia 41-50 tahun dengan persentase 16,32 persen. Hal tersebut dikarenakan pada usia 20-30 adalah usia produktif untuk bekerja.

Tingkat pendidikan terakhir yang mendominasi adalah responden dengan tingkat SMA / SMK yaitu sebanyak 35 responden dengan persentase 71,4 persen, sedangkan persentase terendah didapat dari tingkat pendidikan terakhir Diploma 2 (D2) yaitu 1 responden dengan persentase 2 persen. Hal ini menunjukan pekerjaan pada bidang operasionalnya lebih diutamakan lulusan SMA/SMK, karena SMA/SMK lebih menjurus pada operasional perusahaan.

Pertanyaan-pertanyaan dalam kuisioner dikatakan valid apabila koefisien korelasi $\geq 0,3$. Uji validitas bertujuan untuk memeriksa apakah kuisioner sebagai instrument penelitian sudah tepat untuk mengukur indikator dalam penelitian. Kuisioner dapat dikatakan valid apabila pertanyaan dalam kuisioner mampu mengungkap sesuatu yang akan diukur oleh kuisioner tersebut. Tabel 5 . menunjukkan hasil uji validitas sebagai berikut.

Tabel 5.

Hasil Uji Validitas

\begin{tabular}{ccccc}
\hline Variabel & Indikator & $\begin{array}{c}\text { Koefisien } \\
\text { Korelasi }\end{array}$ & $\begin{array}{c}\text { Korelasi } \\
\text { Batas }\end{array}$ & Keterangan \\
\hline \multirow{3}{*}{ Pengalaman Kerja (X1) } & $\mathrm{X} 1.1$ & 0,774 & 0,3 & Valid \\
& $\mathrm{X} 1.2$ & 0,889 & 0,3 & Valid \\
& $\mathrm{X} 1.3$ & 0,911 & 0,3 & Valid \\
& $\mathrm{X} 2.1$ & 0,810 & 0,3 & Valid \\
Prestasi Kerja (X2) & $\mathrm{X} 2.2$ & 0,870 & 0,3 & Valid \\
& $\mathrm{X} 2.3$ & 0,827 & 0,3 & Valid \\
Pendidikan dan Pelatihan & $\mathrm{X} 2.4$ & 0,853 & 0,3 & Valid \\
(X3) & $\mathrm{X} 3.1$ & 0,757 & 0,3 & Valid \\
& $\mathrm{X} 3.2$ & 0,862 & 0,3 & Valid \\
& $\mathrm{X} 3.3$ & 0,796 & 0,3 & Valid \\
& $\mathrm{X} 3.4$ & 0,800 & 0,3 & Valid \\
Pengembangan Karir (Y) & $\mathrm{Y} .1$ & 0,662 & 0,3 & Valid \\
& $\mathrm{Y} .2$ & 0,759 & 0,3 & Valid \\
& $\mathrm{Y} .3$ & 0,836 & 0,3 & Valid \\
& $\mathrm{Y} .4$ & 0,791 & 0,3 & Valid \\
& $\mathrm{Y} .5$ & 0,625 & 0,3 & Valid \\
& $\mathrm{Y} .6$ & 0,738 & 0,3 & Valid \\
\hline
\end{tabular}

Sumber: Data diolah, 2019 
Hasil uji validitas pada Tabel 5. menunjukkan bahwa seluruh instrumen penelitian yang digunakan untuk mengukur variabel pengalaman kerja, prestasi kerja, pendidikan dan pelatihan, dan pengembangan karir memiliki nilai koefisien korelasi dengan skor total seluruh item pertanyaan lebih besar dari 0,3. Hal ini menunjukkan bahwa butir-butir pertanyaan dalam penelitian tersebut valid dan layak digunakan sebagai instrumen penelitian.

Suatu instrumen dikatakan reliabel, jika instrumen tersebut memiliki nilai cronbach's alpa lebih besar dari 0,60. Hasil dari uji reliabilitas dapat disajikan pada Tabel 6.

Tabel 6.

Hasil Uji Reliabilitas

\begin{tabular}{llcl}
\hline No. & \multicolumn{1}{c}{ Variabel } & $\begin{array}{c}\text { Cronbach's } \\
\text { Alpha }\end{array}$ & Keterangan \\
\hline & & & \\
$\mathbf{1}$ & Pengalaman kerja (X1) & 0,823 & Reliabel \\
$\mathbf{2}$ & Prestasi Kerja (X2) & 0,853 & Reliabel \\
$\mathbf{3}$ & Pendidikan dan Pelatihan (X3) & 0,816 & Reliabel \\
$\mathbf{4}$ & Pengembangan Karir (Y) & 0,823 & Reliabel \\
\hline
\end{tabular}

Sumber: Data diolah, 2019

Hasil uji reliabilitas yang disajikan dalam Tabel 6 menunjukkan bahwa seluruh instrumen penelitian yaitu pengalaman kerja, prestasi kerja, pendidikan dan pelatihan, dan pengembangan karir memiliki koefisien cronbach's alpha lebih dari 0,60. Hal ini dapat dikatakan bahwa semua instrument reliabel sehingga dapat digunakan untuk penelitian.

Metode regresi linier berganda digunakan dalam penelitian ini untuk mengetahui pengaruh Pengalaman Kerja $\left(\mathrm{X}_{1}\right)$, Prestasi Kerja $\left(\mathrm{X}_{2}\right)$, Pendidikan dan Pelatihan $\left(\mathrm{X}_{3}\right)$ Dan Pengembangan Karir $(\mathrm{Y})$. Pengaruh vaiabel bebas terhadap variabel terikat diuji dengan tingkat kepercayaan 95 persen atau $\alpha=5$ persen. Metode ini diuji dengan menggunakan aplikasi SPSS 20.0 for windows diperoleh hasil analisis regresi linier berganda sebagai berikut.

Tabel 7.

Hasil Uji Analisis Regresi Linier Berganda

\begin{tabular}{|c|c|c|c|c|c|}
\hline \multirow[t]{2}{*}{ Model } & \multicolumn{2}{|c|}{$\begin{array}{l}\text { Unstandardized } \\
\text { Coefficients }\end{array}$} & \multirow{2}{*}{$\begin{array}{c}\begin{array}{c}\text { Standardized } \\
\text { Coefficients }\end{array} \\
\text { Beta } \\
\end{array}$} & \multirow[t]{2}{*}{$\mathbf{t}$} & \multirow[t]{2}{*}{ Sig. } \\
\hline & B & Std. Error & & & \\
\hline (Constant) & 5.224 & 2.211 & & 2.362 & .023 \\
\hline Pengalaman Kerja & .492 & .190 & .327 & 2.592 & .013 \\
\hline Prestasi Kerja & .367 & .143 & .321 & 2.558 & .014 \\
\hline Pendidikan dan Pelatihan & .407 & .124 & .333 & 3.287 & .002 \\
\hline R Square & & & & & 0.604 \\
\hline F Statistik & & & & & 22.900 \\
\hline Signifikansi & & & & & 0.000 \\
\hline
\end{tabular}

Berdasarkan hasil analisis regresi linier berganda seperti yang ditunjukkan pada Tabel 7, maka persamaan regresinya adalah sebagai berikut. 


$$
\mathrm{Y}=5,225+0,492 \mathrm{X}_{1}+0,367 \mathrm{X}_{2}+0,407 \mathrm{X}_{3}+\mathrm{e}
$$

Dimana:

$\mathrm{Y}=$ Pengembangan Karir

$\mathrm{X}_{1}=$ Pengalaman Kerja

$\mathrm{X}_{2}=$ Prestasi Kerja

$\mathrm{X}_{3}=$ Pendidikan dan Pelatihan

Persamaan regresi linier berganda tersebut menunjukan arah masing-masing variabel bebas terhadap variabel terikatnya. $X_{1}=+0,492$, menunjukan bahwa pengalaman kerja $\left(\mathrm{X}_{1}\right)$ berpengaruh positif terhadap pengembangan karir $(\mathrm{Y}) \mathrm{di}$ Uppala Villa \& SPA Umalas. $\mathrm{X}_{2}=+0,367$, menunjukan bahwa prestasi kerja $\left(\mathrm{X}_{2}\right)$ berpengaruh positif terhadap pengembangan karir (Y) di Uppala Villa \& SPA Umalas. $\mathrm{X}_{3}=+0,407$, menunjukan bahwa pendidikan dan pelatihan $\left(\mathrm{X}_{3}\right)$ berpengaruh positif terhadap pengembangan karir (Y) di Uppala Villa \& SPA Umalas. $\mathrm{R}^{2}=0,604$, yang berarti bahwa sebesar 60,4 persen variabel Pengembangan Karir (Y) dipengaruhi oleh Pengalaman Kerja $\left(\mathrm{X}_{1}\right)$, Prestasi Kerja $\left(\mathrm{X}_{2}\right)$, dan Pendidikan dan Pelatihan $\left(\mathrm{X}_{3}\right)$, Sedangkan sisanya sebesar 39,6 persen dipengaruhi oleh variabel lainnya di luar model penelitian.

Uji normalitas bertujuan untuk mengetahui apakah residual dari model regresi yang dibuat berdistribusi normal atau tidak. Uji normalitas pada penelitian ini menggunakan uji kolmogrovo-Smirnov data berdistribusi normal jika sig (2tailed) lebih besar dari 0,05 ( $\alpha=5$ persen). Tabel 8 menunjukkan hasil uji normalitas.

Tabel 8.

Hasil Uji Normalitas

\begin{tabular}{cc}
\hline & Unstandardized Residual \\
\hline $\mathrm{N}$ & 49 \\
Kolmogorov-Smirnov $Z$ & 0,083 \\
Asymp. Sig. (2-tailed) & 0,200 \\
\hline
\end{tabular}

Sumber: Data diolah, 2019

Tabel 8. menunjukkan bahwa nilai Kolmogorov-Smirnov (K-S) sebesar 0,083, sedangkan nilai Asymp. Sig. (2-tailed) sebesar 0,200 yaitu lebih besar dari $0,05(0,200>0,05)$. Dengan demikian data tersebut telah memenuhi syarat normalitas dan data tersebut dinyatakan berdistribusi normal.

Uji Multikolenearitas bertujuan untuk menguji apakah pada model regresi ditemukan adanya korelasi antar variabel bebas. Untuk mendeteksi ada atau tidaknya korelasi antar sesame variabel bebas dilihat dari nilai tolerance dan nilai inflation factor (VIF). Apabila nilai tolerance rendah sama dengan nilai VIF tinggi karena VIF $=\mathrm{I} /$ tolerance . Dengan kata lain, tidak terjadi multikolinearitas apabila memiliki nilai $\mathrm{VIF}<10$ dan mempunyai angka tolerance $>0,10$. Tabel 9 menunjukkan hasil uji multikolinearitas.

Tabel 8. menunjukkan bahwa nilai tolerance dan VIF dari variabel pengalaman kerja, prestasi kerja dan pendidikan dan pelatihan. Berdasarkan hasil analisis, dapat dilihat bahwa koefisien tolerance semua variabel lebih besar dari 0,10 dan nilai VIF yang lebih kecil dari 10 yang berarti model persamaan regresi bebas dari multikolineartitas. 
Tabel 9.

Hasil Uji Multikolinearitas

\begin{tabular}{lcc}
\hline & \multicolumn{2}{c}{ Colinearity Statistic } \\
\cline { 2 - 3 } Model & Tolerance & VIF \\
\hline Pengalaman Kerja & 0.554 & 1.806 \\
Prestasi Kerja & 0.559 & 1.790 \\
Pendidikan dan Pelatihan & 0.859 & 1.163 \\
\hline Sumber: Data diolah, 2019 & &
\end{tabular}

Uji heteroskedastisitas dipergunakan untuk mengetahui apakah ada atau tidaknya gejala heteroskedastisitas antara residual pengamatan yang pertama dengan pengamatan lainnya yang dilakukan dengan uji glejser. Jika tidak ada satupun variabel bebas yang berpengaruh signifikan terhadap nilai absolute residual atau nilai signifikansinya diatas 0,05 maka model regresi dikatakan bebas dari gejala heteroskedastisitas. Tabel 10. menunjukkan hasil uji heteroskedastisitas.

Tabel 10.

Hasil Uji Heteroskedastisitas

\begin{tabular}{llrrrrr}
\hline Model & \multicolumn{2}{c}{$\begin{array}{c}\text { Unstandardized } \\
\text { Coefficients }\end{array}$} & $\begin{array}{c}\text { Standardized } \\
\text { Coefficients }\end{array}$ & & \\
\cline { 2 - 5 } & \multicolumn{1}{c}{ B } & Std. Error & Beta & \multicolumn{1}{c}{ T } & \multicolumn{1}{c}{ Sig. } \\
\hline 1 (Constant) & 2.823 & 1.330 & & 2.122 & .039 \\
& Pengalaman Kerja & -.124 & .114 & -.210 & -1.084 & .284 \\
& Prestasi Kerja & .078 & .086 & .175 & .907 & .369 \\
& Pendidikan dan & -.093 & .075 & -.193 & -1.244 & .220 \\
& Pelatihan & & & & & \\
\hline
\end{tabular}

Sumber: Data diolah, 2019

Tabel 10. menunjukkan bahwa nilai sig. dari variabel pengalaman kerja, prestasi kerja, dan pendidikan dan pelatihan masing-masing sebesar 0,284, 0,369 dan 0,220. Nilai tersebut lebih besar dari 0,05 yang berarti tidak terdapat pengaruh antara variabel bebas terhadap absolute residual. Dengan demikian, model yang dibuat tidak mengandung gejala heteroskedastisitas.

Uji kelayakan model atau yang lebih populer disebut sebagai uji F merupakan tahapan awal mengidentifikasi model regresi yang diestimasi layak atau tidak. Layak (andal) disini maksudnya adalah model yang diestimasi layak digunakan untuk menjelaskan pengaruh variabel-variabel bebas terhadap variabel terikat. Nama uji ini disebut sebagai uji F, karena mengikuti mengikuti distribusi $F$ yang kriteria pengujiannya seperti One Way Anova.

Sig. Tabel ANOVA menunjukkan besarnya angka probabilitas atau signifikansi pada perhitungan ANOVA. Nilai yang tertera digunakan untuk uji kelayakan model analisis (dimana sejumlah variabel $\mathrm{X}$ mempengaruhi variabel $\mathrm{Y}$ ) dengan ketentuan angka probabilitas yang baik untuk digunakan sebagai model regresi harus $<0,05$. Nilai ini bisa dilihat pada kolom Sig. Jika Sig. $<0,05$, maka model analisis dianggap layak. Jika Sig. > 0,05, maka model analisis dianggap tidak layak.

Tabel 11. menunjukkan nilai Sig. sebesar 0,000 yang lebih kecil dari 0,05 (sig $<\alpha)$ yang berarti variabel bebas yaitu pengalaman kerja $\left(X_{1}\right)$, prestasi kerja $\left(X_{2}\right)$, dan pendidikan dan pelatihan $\left(\mathrm{X}_{3}\right)$ berpengaruh signifikan secara serempak atau 
bersama-sama terhadap variabel terikat yaitu pengembangan karir (Y), sehingga penelitian ini dapat dikatakan memenuhi uji kelayakan model atau model penelitian ini dinyatakan layak digunakan sebagai model regresi.

Tabel 11.

Hasil Uji Kelayakan Model (Uji F)

\begin{tabular}{|c|c|c|c|c|c|}
\hline Model & Sum of Squares & Df & Mean Square & $\mathbf{F}$ & Sig. \\
\hline 1 Regression & 164.596 & 3 & 54.865 & 22.900 & $.000^{\mathrm{b}}$ \\
\hline Residual & 107.812 & 45 & 2.396 & & \\
\hline Total & 272.408 & 48 & & & \\
\hline
\end{tabular}

Sumber: Data diolah, 2019

Koefisien determinasi ( $R$ Square) berguna untuk mengukur besarnya kontribusi variabel bebas (pengalaman kerja, prestasi kerja dan pendidikan dan pelatihan) terhadap variabel terikat (pengembangan karir). Dengan menggunakan aplikasi SPSS 20.0 for windows diperoleh hasil analisis sebagai berikut.

Tabel 12.

Hasil Analisis Koefisien Determinasi $\left(\mathbf{R}^{2}\right)$

\begin{tabular}{lcccc}
\hline Model & $\mathbf{R}$ & R Square & $\begin{array}{c}\text { Adjusted R } \\
\text { Square }\end{array}$ & $\begin{array}{c}\text { Std. Error of the } \\
\text { Estimate }\end{array}$ \\
\hline 1 & $.777^{\mathrm{a}}$ & .604 & .578 & 1.548 \\
\hline Sumber: Data diolah, 2019 & & & &
\end{tabular}

Tabel 12. menunjukkan bahwa nilai $R$ Square sebesar 0,604 sehingga dapat dihitung persentase kontribusi pengalaman kerja, prestasi kerja dan pendidikan dan pelatihan terhadap pengembangan karir sebesar $0,604 \times 100$ persen $=60,4$ persen, sedangkan sisanya sebesar 39,6 persen dipengaruhi oleh variabel lainnya di luar model penelitian.

Uji t dipergunakan untuk menguji pengaruh dari variabel pengalaman kerja, prestasi kerja dan pendidikan dan pelatihan terhadap variabel pengembangan karir karyawan terikatnya secara parsial. Kriteria pengujian untuk menjelaskan interpretasi pengaruh antar masing-masing variabel adalah sebagai berikut.

Jika Sig. $\mathrm{t}<0.05$ maka $\mathrm{H}_{0}$ ditolak dan $\mathrm{H}_{1}$ diterima.

Jika Sig. $\mathrm{t}>0.05$ maka $\mathrm{H}_{0}$ diterima dan $\mathrm{H}_{1}$ ditolak.

Berdasarkan Tabel 7. hasil uji t, diketahui bahwa variabel pengalaman kerja memiliki nilai koefisien beta positif sebesar 0,327 dengan Sig. sebesar 0,013. Nilai Sig. 0,013 $<0,05$ mengindikasikan bahwa $\mathrm{H}_{0}$ ditolak dan $\mathrm{H}_{1}$ diterima. Hasil ini mempunyai arti bahwa Pengalaman Kerja memiliki pengaruh positif dan signifikan terhadap Pengembangan Karir. Berdasarkan Tabel 7. hasil uji t, diketahui bahwa variabel prestasi kerja memiliki nilai koefisien beta positif sebesar 0,321 dengan Sig. sebesar 0,014. Nilai Sig. 0,014 <0,05 mengindikasikan bahwa $\mathrm{H}_{0}$ ditolak dan $\mathrm{H}_{2}$ diterima. Hasil ini mempunyai arti bahwa Prestasi Kerja memiliki pengaruh positif dan signifikan terhadap Pengembangan Karir.

Berdasarkan Tabel 7. hasil uji t, diketahui bahwa variabel pendidikan dan pelatihan memiliki nilai koefisien beta positif sebesar 0,333 dengan Sig. sebesar 0,002. Nilai Sig. 0,002<0,05 mengindikasikan bahwa $\mathrm{H}_{0}$ ditolak dan $\mathrm{H}_{3}$ diterima. 
Hasil ini mempunyai arti bahwa Pendidikan dan Pelatihan memiliki pengaruh positif dan signifikan terhadap Pengembangan Karir.

Hasil penelitian menunjukan bahwa pengalaman kerja memiliki pengaruh positif dan signifikan terhadap pengembangan karir yang berarti apabila pengalaman kerja semakin lama maka pengembangan karir yang dimiliki karyawan akan meningkat, dan sebaliknya apabila pengalaman kerja karyawan kurang maka pengembangan karir yang dimiliki karyawan akan menurun. Hasil penelitian ini sesuai dengan hipotesis satu $\left(\mathrm{H}_{1}\right)$ yang diajukan dan sesuai dengan penelitian yang dilakukan oleh Kristola (2014); A, Sihotang (2007); Adnyani (2019); Afrizal (2014); Ahmadi (2004); Ali (2013); Andriyani (2017), Ardana et al. (2012); Arisandy (2015); Asim et al. (2012); Rivai (2011); Riyadi (2015); Oertle et al. (2007); Nugraha (2014); Dewi \& Kartika (2015); Suadnyana (2018) Saraswati \& Andani (2017) yang menyatakan pengalaman kerja memiliki pengaruh positif dan signifikan terhadap pengembangan karir karyawan. Hasil kuisioner menunjukan bahwa skor rata-rata dari 3 pernyataan mengenai pengalaman kerja yaitu sebesar 4,05 yang berarti pengalaman kerja karyawan tergolong lama.

Hasil penelitian menunjukan bahwa prestasi kerja memiliki pengaruh positif dan signifikan terhadap pengembangan karir yang berarti semakin tinggi prestasi kerja maka pengembangan karir karyawan akan meningkat dan sebaliknya semakin rendah prestasi kerja maka pengembangan karir karyawan kan semakin menurun. Hasil penelitian ini sesuai dengan hipotesis dua $\left(\mathrm{H}_{2}\right)$ yang diajukan dan sesuai dengan penelitian yang dilakukan oleh Rawashdeh (2013); Wati \& Mira (2015); Wati \& Mira (2015); Muamarizal et al. (2015); Susanto (2013); Sumadewi (2017) menyatakan prestasi kerja memiliki pengaruh positif dan signifikan terhadap pengembangan karir. Hasil kuisioner menunjukan bahwa rata-rata skor dari 4 pernyataan mengenai prestasi kerja yaitu sebesar 4,02 yang berarti prestasi kerja tergolong tinggi.

Hasil penelitian menunjukan bahwa pendidikan dan pelatihan memiliki pengaruh positif dan signifikan terhadap pengembangan karir yang berarti semakin tinggi pendidikan dan pelatihan maka pengembangan karir karyawan akan meningkat dan sebaliknya semakin rendah pendidikan dan pelatihan maka pengembangan karir karyawan akan semakin menurun. Hasil penelitian ini sesuai dengan hipotesis dua $\left(\mathrm{H}_{3}\right)$ yang diajukan dan sesuai dengan penelitian yang dilakukan oleh Adnyani (2019); Andriyani (2017); Candra (2016); Nugraha (2014 Saranani (2015). Adnyani (2019). Menyatakan pendidikan dan pelatihan memiliki pengaruh positif dan signifikan terhadap pengembangan karir. Hasil kuisioner menunjukan bahwa rata-rata skor dari 4 pernyataan mengenai pendidikan dan pelatihan sebesar 3,83 yang berarti pendidikan dan pelatihan pada karyawan telah berjalan dengan tepat.

Hasil penelitian ini memiliki implikasi teoritis dan praktis. Secara teoritis penelitian ini menunjukan bahwa pengalaman kerja, prestasi kerja dan pendidikan dan pelatihan berpengaruh positif dan signifikan terhadap pengembangan karir karyawan. Dengan demikian, hasil penelitian ini memberikan dukungan empiris dan dapat dinyatakan memperkuat hasil-hasil studi terdahulu. Secara praktis dari penelitian ini diharapkan bagi pemimpin di Uppala Villa \& SPA Umalas dapat lebih memperhatikan pengembangan karir karyawan yang dipengaruhi oleh pengalaman 
kerja, prestasi kerja dan pendidikan dan pelatihan ini yang ditunjukan oleh koefisien determinasi sebesar 60,4 persen, namun diperhatikan juga faktor lain yang mempengaruhi pengembangan karir karyawan.

Terdapat keterbatasan yang mempengaruhi kondisi dari penelitian yang dilakukan. Adapun keterbatasan dalam penelitian ini yaitu: responden hanya karyawan Uppala Villa \& SPA Umalas, sehingga hasil penelitian ini hanya dapat diterapkan dilingkungan kerja Uppala Villa \& SPA Umalas dan tidak dapat digeneralisasi pada lingkungan perusahaan lain. Faktor-faktor yang mempengaruhi perkembangan karir karyawan dalam penelitian ini hanya terdiri dari tiga variabel, yaitu pengalaman kerja, prestasi kerja dan pendidikan dan pelatihan, sedangkan masih banyak faktor lain yang mempengaruhi perkembangan karir. Penelitian ini menggunakan kuisioner sebagai instrumen penelitian yaitu jawaban dari responden terkadang kurang menunjukan keadaan yang sesungguhnya.

\section{SIMPULAN}

Berdasarkan hasil penelitian yang dilakukan dan hasil pembahasan yang telah dipaparkan maka dapat ditarik kesimpulan bahwa pengalaman kerja berpengaruh positif dan signifikan terhadap pengembangan karir karyawan Uppala Villa \& SPA Umalas. Hal ini menunjukan semakin lama pengalaman kerja yang dimiliki maka pengembangan karir juga akan meningkat. Prestasi kerja berpengaruh positif dan signifikan terhadap pengembangan karir karyawan di Uppala Villa \& SPA Umalas. Hal ini menunjukan semakin tinggi prestasi kerja yang dimiliki maka pengembangan karir juga akan meningkat. Pendidikan dan pelatihan berpengaruh positif dan signifikan terhadap pengembangan karir karyawan di Uppala Villa \& SPA Umalas. Hal ini menunjukan semakin tepat pendidikan dan pelatihan yang dilakukan maka pengembangan karir juga akan meningkat.

Berdasarkan simpulan yang telah diuraikan, maka dapat diajukan saran yaitu berdasarkan hasil penelitian mengenai pengembangan karir menunjukkan bahwa skor rata-rata terendah yaitu pada pernyataan "Saya merasa cukup memiliki informasi mengenai promosi jabatan yang ada di perusahaan". Pihak manajemen Uppala Villa \& SPA Umalas sebaiknya lebih memperhatikan pengembangan karir para karyawan, terutama dalam memberikan informasi mengenai promosi jabatan. Hal ini dilakukan agar karyawan mengetahui apabila ada informasi mengenai promosi jabatan agar karir karyawan dapat berkembang. Berdasarkan hasil penelitian mengenai pengalaman kerja menunjukkan bahwa skor rata-rata terendah yaitu pada pernyataan "Pengalaman kerja yang saya miliki memicu keterampilan kerja saya". Pihak manajemen Uppala Villa \& SPA Umalas sebaiknya lebih memperhatikan pengalaman kerja para karyawan, terutama dalam meningkatkan keterampilan karyawan. Hal ini dilakukan agar karyawan mampu menyelesaikan dan bertanggung jawab atas tugas yang diberikan dengan lancar dan dapat mengembangkan karirnya pada bidang masing-masing.

Berdasarkan hasil penelitian mengenai prestasi kerja menunjukkan bahwa skor rata-rata terdendah yaitu pada pernyataan "saya mampu memaksimalkan kinerja untuk memperoleh hasil terbanyak dan meminimalisir terjadinya kerugian". Pihak manajemen Uppala Villa \& SPA Umalas sebaiknya lebih memperhatikan 
hasil kinerja karyawannya, khususnya karyawan yang masih belum mampu memaksimalkan kinerjanya. Karyawan yang memiliki prestasi kerja rendah sebaiknya lebih diberikan program pendidikan dan pelatihan. Hal ini dilakukan agar karyawan mampu bekerja secara maksimal dan memiliki prestasi yang tinggi agar dapat mengembangkan karirnya. Berdasarkan hasil kuisioner mengenai pendidikan dan pelatihan menunjukkan bahwa skor rata-rata terendah yaitu pada pernyataan "Metode pendidikan dan pelatihan yang digunakan dapat mudah dipahami dalam penyampaian materi". Pihak manajemen Uppala Villa \& SPA Umalas sebaiknya tetap mempertahankan dan meningkatkan pelaksanaan pendidikan dan pelatihan, khususnya dalam meningkatkan metode pendidikan dan pelatihan yang digunakan agar lebih dapat mudah dipahami karyawan.

Hal ini dilakukan agar karyawan memiliki kemampuan dan wawasan yang lebih baik mengenai bidang yang mereka tekuni serta dapat meningkatkan pengembangan karir yang mereka inginkan. Penelitian selanjutnya diharapkan untuk mengkaji lebih banyak sumber maupun refrensi yang terkait dengan variabel penelitian, serta mempertimbangkan variabel-variabel lain yang mempengaruhi pengembangan karir.

\section{REFERENSI}

A, Sihotang. (2007). Manajemen Sumber Daya Manusia. Jakarta: Pradnya Paramita.

Adnyani, R. (2019). Pengaruh Pengalaman Kerja, Prestasi Kerja dan Pelatihan Terhadap Pengembangan Karier Karyawan di Wapa di Ume Resort \& Spa. E-Jurnal Manajemen, 8(7), 4073-4101.

Ali, S. M., Shaharudin, M. R., \& Anuar, A. (2013). The Association between Job Positions, Work Experience and Career Satisfaction: The Case of Malaysian's Academic Staff. Journal Asian Social Science, 8(10), 35-44.

Andriyani, N. P. D. (2017). Pengaruh Pendidikan dan Pelatihan, Pengalaman Kerja dan Pengembangan Karir Pada PDAM Tirta Mangutama Kabupaten Badung. E-Jurnal Manajemen Universitas Udayana, 11(6), 5859-5882.

Ardana, I K, Mujiati, N. W., Utama, I Wayan Mudiartha;. (2012). Manajemen Sumber Daya Manusia. Edisi Pertama. Yoygakarta: Graha Ilmu.

Arisandy, M. R. (2015). Pengaruh Keterampilan Dan Pengalaman Kerja Terhadap Pengembangan Karir Pegawai Pada Dinas Pendidikan Kabupaten Donggala. e-Jurnal Katalogis, 3(8), 149-156.

Asim, A. I., Waqas, M., \& Cheema, L. J. (2012). Mediating Character of Readness to Change Between Training \& Development And Employess Performance. Arabian Journal of Business and Management Riview, 2(1), 1-11. 
Butcher, S., \& Wilton, R. (2008). Stuck in transition Exploring the spaces of employment training for youth with intellectual disability. Geoforum 39, 1079-1092.

Candra, N. N. W. (2016). Pengaruh Pengalaman Kerja, Pendidikan dan Pelatihan Terhadap Pengembangan Karir di PT. PLN (Persero) Distribusi Bali. EJurnal Manajemen Universitas Udayana, 9(5), 5839-5867.

Caroline, O., and Susan. (2014). Influence of Career Development on Employee Performance in The Public University, A Case of Kenyata University. International Journal of Sciences Management and Enterpreneurship, 1(2), $1-16$.

Charity, B. C. (2015). Effect Of Training And Career Development On Employee Performance: A Case Of Kcb Branches In The North Rift Region, Kenya. International Journal of Advanced Research in Management and Social Sciences, 4(5), 38-49.

Crowley, Marian, \& Henry. (2012). Re-conceptualizing The Career Development Of Self Initiated Expatriates: Rivers Not Ladders. Journal Of Management Delevopment, 31(2), 130-141.

Dewi, I. A. P. K. (2015). Pengaruh Penilaian Kinerja dan Pengalaman Kerja Terhadap Pengembangan Karir Pada PT Bali Biasa Indah Koleksi Kuta - Bali. E-Jurnal Manajemen Universitas Udayana, 7(4): 1918-1933.

Falola H. O., Osibanjo, A. O. \& Ojo, S.I. (2014). Effectiveness of Training and Development on Employees' Performance and Organisation Competitiveness in the Nigerian Banking Industry. Bulletin of the Transilvania University of Braşov, 7(1), 161-170.

Ghozali, I. (2009). Aplikasi Analisis Multivariate dengan Program SPSS . Semarang: Badan Penerbit Universitas Diponegoro.

Hasibuan, M. (2013). Manajemen Sumber Daya Manusia. Jakarta: PT. Bumi Aksara.

Hasibuan. M. (2001). Manajemen Sumber Daya Manusia. Edisi Revisi. Jakarta: PT. Bumi Aksara.

Hidayat \& Nurasyiah. (2016). Pengaruh Diklat (Pendidikan dan Pelatihan) Terhadap Prestasi Kerja Karyawan di Bank BPR Rokan Hulu. Jurnal Ilmiah Cano Ekonomos, 6(1). 
Kakul, I. M., \& Gachunga, D. H. (2016). Effects Of Career Development On Employee Performance In The Public Sector: A Case Of National Cereals And Produce Board. www.strategicjournals.com, 3(3), 307-324.

Kasmuni, Aji; Minarsih, Maria M.; Wulan, Heru Sri;. (2016). Pengaruh Kompensasi, Pendidikan dan Pelatihan Terhadap Prestasi Kerja Karyawan PT. Woodexindo Semarang. Journal of Management, 2(2).

Khan, A. Sami, James Rajasekar and Ahmed Al-Asfour. (2015). Organizational Career Development Practices: Learning from an Omani Company. International Journal of Business and Management, 10(9), 42-45.

Kristola, Dio. (2014). Pengaruh Diklat dan Pengalaman Kerja Terhadap Prestasi Kerja Serta Dampaknya Terhadap Pengembangan Karir Pegawai di Balai Karantina Pertanian Kelas 1 Denpasar. E-Jurnal Manajemen Universitas Udayana, 4(3): 902-921.

Li, J., \& Ronald, K. Y. (2011). Quality of Work Life and Career Development: Perceptions of Part-Time MBA Student. Journal Employee Relations, 33(2), 201-220.

Muamarizal, S., Samsudin., \& Marzolina. (2015). Pengaruh Pengalaman Kerja Dan Penilaian Prestasi Kerja Terhadap Pengembangan Karir Karyawan pada PT. Jasaraharja Putera Cabang Pekanbaru. JOM FEKON, 2(1).

Nugraha, I G. N. W. (2014). Pengaruh Pendidikan Dan Pelatihan (Diklat) Dan Pengalaman Kerja Terhadap Prestasi Kerja Dan Pengembangan Karir Pada Karyawan Baleka Beach Resort Badung. E-Journal Manajemen Unud, 3(8), 2167-2181.

Oertle, K. M., \& Trach, J. S. . (2007). Interagency collaboration: The importance of Rehabilitation Professionals' Involvement in Transition. Journal of Rehabilitation, 73(3), 36-44.

Rawashdeh, A. S. (2013). Impact of Human Resource Systems and Practices on Attitutdes Toward Career Development Programs in the Banking Sector of Jordan. European Scientific Journal, 9(19) 236-252.

Rivai, V. (2011). Manajemen Sumber Daya Manusia Untuk Perusahaan. Jakarta: PT. Raja Grafindo Persada.

Saeed, I., Waseem, M., Sikander, S., \& Rizwan, M. (2014). The relationship of Turnover intention with job satisfaction, job performance, Leader member exchange, Emotional intelligence and organizational commitment. International Journal of Learning \& Development , 4(2), 242-256. 
Saranani, F. (2015). Effect Of Education And Training To Performance Mediated Career Development Inspectorate City Employees Kendari . The International Journal Of Engineering And Science (IJES), 4(3), 28-36.

Saraswati, K. A. (2017). Pengaruh Pengalaman Kerja, Pendidikan, dan Kepribadian Terhadap Pengembangan Karir Karyawan Pada Hotel Nikki di Denpasar. EJurnal Manajemen Universitas Udayana, 11(6): 6167-6186.

Siagian, S. P. (2016). Manajemen Sumber Daya Manusia. Edisi 1, Cet. 24. Jakarta: Bumi Aksara.

Soeprihanto, J. (2009). Penilaian Kinerja dan Pengembangan Karyawan. Edisi 1.

Suadnyana, I Kadek. (2018). Pengaruh Penilaian Kinerja, Pengalaman Kerja, Dan Pelatihan Terhadap Pengembangan Karir di Bali Masari Villas and SPA. EJurnal Manajemen Universitas Udayana, 4(7): 1950-1978.

Sugiyono. (2012). Metode Penelitian Bisnis (pendekatan kuantitatif, kualitatif dan $R \& D)$. Bandung: Alfabeta.

Sumadewi, N. P. A. (2017). Pengaruh Pengalaman Kerja, Prestasi Kerja, Pendidikan dan Pelatihan Terhadap Pengembangan Karir Pada Perawat PNS Rumah Sakit Umum Daerah Badung Mangusada. E-Jurnal Manajemen Universitas Udayana, 8(6): 4070-4098.

Sunyoto, Danang. (2012). Manajemen Sumber Daya Manusia. Jakarta: PT Buku Seru.

Susanto P., Sari R. D. (2013). Pengaruh Pendidikan Dan Prestasi Kerja Terhadap Pengembangan Karir Pada Karyawan Koperasi Keluarga Besar PT. Semen Padang. Jurnal Kajian Manajemen Bisnis, 2(2), 3727.

Sutrisno, Edy. (2009). Manajemen Sumber Daya Manusia. Jakarta: Kencana.

Wati, M. (2015). Pengaruh Kualitas Kerja dan Prestasi Kerja terhadap Pengembangan Karir Karyawan pada PT. Bank Tabungan Negara Padang. EJournal Universitas Taman Siswa Padang, 4(1), 1-86.

Wirawan, Nata. (2009). Cara Mudah Memahami Statistik 2 (Statistik Inferensial) Untuk Ekonomi dan Bisnis. Denpasar: Keraras Emas.

Zainullah, A., Suharyanto, A. \& Budio, S. P. (2013). Pengaruh Upah, Kemampuan dan Pengalaman Kerja Terhadap Kinerja Pekerja Pelaksanaan Bekisting Pada Pekerjaan Beton. Jurnal Rekayasa Sipil, 6(2), 125-133. 
Ida Ayu Diah Sri Gayatri, Pengaruh Pengalaman Kerja...

Zhan, W., \& Zhou, X. (2008). Intraorganizational Career Advancement and Voluntary Turnover In a Multinational Bank In Taiwan. Journal Career Development, 2(1), 402-424. 